\title{
Influence of Pine (Pinus sylvestris L.) Growth Rings Width on the Strength Properties of Structural Sawn Timber
}

Piotr Mankowski, Izabela Burawska-Kupniewska,* Slawomir Krzosek, and Marek Grzeskiewicz

\begin{abstract}
Annual growth ring width was considered relative to the mechanical properties of timber from the Silesian Forestry Region in Poland. The timber was acquired from raw wood aged approximately 120 years old, with $\log$ quality $A, B$, and $C$. The study was conducted on 210 pieces of timber; 70 of them were from each part of the log: butt, middle, and top. The tested parameters, modulus of elasticity (MOE) and modulus of rupture $(\mathrm{MOR})$, were measured on fully dimensional timber $(40 \times 138 \times$ $3500 \mathrm{~mm}^{3}$ ) that had been dried and planed in industrial conditions. The density of wood (stereometric method) and annual rings width were calculated after MOR and MOE determination on samples including the entire cross-section cut near the failure zone. The tests revealed that the correlation between the width of growth rings and MOE or MOR depended on the log area: it was the highest for timber from butt logs and the lowest for timber from top logs. Moreover, the correlation between growth ring width and MOE or MOR depended also on the quality class of the logs from which the samples were obtained: it was the highest for timber from class $\mathrm{A}$, and the lowest for class $\mathrm{C}$.
\end{abstract}

Keywords: Pine timber; MOR; MOE; Density; Annual growth rings width

Contact information: Institute of Wood Sciences and Furniture, Warsaw University of Life Sciences SGGW, 159 Nowoursynowska St., 02-776 Warsaw, Poland;

* Corresponding author: izabela_burawska@sggw.pl

\section{INTRODUCTION}

The width of annual growth rings is easy to measure, and it characterises wooden raw material quite well. Growth ring width is measured on the cross-section. In case of lack of access to the cross-section, the width of growth rings can be measured using a Pressler's drill (Gao et al. 2017), a resistograph (Bouffier et al. 2008), or computed tomography (Brüchert et al. 2008; Steffenrem et al. 2014).

Wood density and annual growth rings' width change together with age (Niklas 1997), trunk height (Tomczak et al. 2007), and position relative to the trunk's pith ray (Gartner et. al. 2002). Quite often, the width of annual growth rings is treated as an indicator of the technical properties of wood. Previous studies investigated correlations between annual growth rings and wood density (Gartner et al. 2002) as well as compressive strength parallel to the grain (Giagli et al. 2019).

The rules of safe introduction of construction materials into the European market are regulated by the directive 89/106/EEC, which has been replaced by the Regulation no. 305/2011 of the European Parliament and of the Council. The directive defines a list of basic requirements for construction products and sets the rules of granting the CE mark for 
them. According to this directive, a construction product can receive the CE mark (deemed safe) only if it was manufactured in line with the requirements given in the harmonised standard. In a situation where there is no harmonised standard that gives requirements for a specific product, service, or process, a construction product still can receive the CE mark if it was manufactured in line with the European Technical Approval (ETA). A harmonised standard is a standard that has been published in the Official Journal of the European Union (OJEU). The manufacturer of construction materials who wants to have the right to mark their products with the CE sign has to cooperate with an independent notified institution to confirm that they meet a series of requirements (e.g. carry out a preliminary test of type, implement production control in the production plant, and obtain the pertinent certificates). The full list of requirements depends on the control/assessment system applied to the specific product. The 89/106/EEC Directive introduced the control systems: $1+, 1,2+, 2$, 3 and 4. According to the Regulation no. 305/2011, the systems that are binding currently are: $1+, 1,2+, 3$, and 4 . In case of solid wood for construction applications (control system $2+)$ the harmonised standard is the EN 14081-1 (2015), for construction laminate made of glued timber layers (control system 1) the harmonised standard is the EN 14080 (2013), and for solid construction wood connected with multi-wedge joints (control system 1): EN 15497 (2014).

The production processes of the above-mentioned kinds of wood used in construction must make use of strength-graded timber. There are two methods of strength grading: visual and machine assisted. The machine assisted method classifies wood into $\mathrm{C}$ strength classes. The resistance parameters of timber classified to different $\mathrm{C}$ strength classes (the characteristic strength values, stiffness values and density values) are defined in EN 338 (2016).

Each EU member state has its own, national standard regulating the strength grading process with the visual method, which should be in line with the harmonised standard EN 14081-1 (2015). Visual strength grading divides timber into sorting or grading classes. In Poland, visual strength grading is carried out on the basis of the PN/D-94021 (2013) standard, in Germany: DIN 4074-1 (2012), in Great Britain: BS 4978 (2007) + A1(2011), in Austria: ÖN DIN 4074 (2012), in Slovakia: STN 491531 (2001) + Z1(2006), in Italy: UNI 11035-2 (2010), and in France NF B 52-001-1 (2011), etc. The grading classes functioning as a result of applying those standards are the following: in Poland: KW - high quality grade, KG - grade of less quality; Germany: S13, S10 and S7; Great Britain: SS and GS; Austria: S13, S10 and S7; Slovakia: S0, SI and SII; Italy has the classes S1, S2 and S3 for pine timber; France: TI, TII, TIII and TIV (for elements with the cross section of $16000 \mathrm{~mm} 2$ and less). In view of such huge diversity of strength classes used in visual strength grading in Europe, it became necessary to unify and harmonise them. This unification consists of specifying which national classes correspond to which European strength classes "C" introduced by EN 338 (2016). The corresponding classes have been described in the standard EN 1912 (2012). Polish sorting classes: KW, KS, and KG, have not been included in EN 1912 (2012) so far.

The visual strength grading method consists of examining every piece of timber carefully and classifying it in the appropriate grading class on the basis of visible defects of wood structure, shape, and processing. The following structural wood defects are taken into account: knots, twisted fibres, cracks, resin pockets, inbarks, wounds, rot, insect tunnels, and the presence of sclerenchyma. The defects of shape and processing taken into account during visual strength grading are the following: wanes, bows, cups, springs, warping, and other defects due to the wrong processing, such as ends whose surfaces are 
not parallel. Moreover, the width of annual growth rings of the graded timber is also one of the criteria of visual strength grading. The standards of visual strength grading specify the maximum permitted average growth ring width in each of the grading classes, as well as the methodology of measurement of this parameter. According to the Polish standard regulation the process of visual strength grading, PN-D-94021 (2013), timber is classified in one of three grading classes: KW (the best), KS (medium), and KG (the worst). The criterion concerning growth ring width is the following: the maximum permitted growth ring width in the $\mathrm{KW}$ class is $4 \mathrm{~mm}$, timber in the $\mathrm{KS}$ class can have the average width of growth rings not greater than $6 \mathrm{~mm}$, and the growth ring width of timber in the KG class cannot exceed $10 \mathrm{~mm}$. It is known that for coniferous wood, narrow growth rings have better strength parameters than wood with wide growth rings. The annual growth ring width is correlated with the bending strength, modulus of elasticity (MOE), and density of wood. These relations have already been the subject of multiple studies. The coefficient of determination between the width of annual growth rings and bending strength for spruce wood falls between 0.20 (Hoffmeyer 1990) and 0.44 (Lackner and Foslie 1988). According to other studies of spruce wood, this coefficient is between 0.15 and 0.35 (Denzler 2007), while for European coniferous species it amounts to 0.4 (Glos 1982).

A research of pine timber from five selected Polish forestry regions permitted to determine that the coefficient of determination between the width of annual growth rings and bending strength for the entire batch of timber under research amounted to 0.27 (Krzosek 2009).

Large dimension, round coniferous logs are logs whose diameter on the narrower end, measured without bark, equals or exceeds $14 \mathrm{~cm}$. The quality classification of this kind of wood in Poland is completed in relation to the PN-D-95017 (1992) standard. Recently, the Polish Committee for Standardization (PKN) deemed that the standard was no longer binding, but it is still being habitually used, together with the related Resolutions issued by the General Director of National Forests. According to the standard, largedimension coniferous wood can be classified into four quality classes: A, B, C, and D. The A class is the best one, while D corresponds to the lowest quality. In the D class, at least $40 \%$ of volume of each piece should be adequate for further processing and use. The standard sets the smallest diameter, without bark, at the narrower end: $22 \mathrm{~cm}$ for class A, and $14 \mathrm{~cm}$ for the remaining classes. The smallest diameter at the distance of $1 \mathrm{~m}$ from the thicker end (the nominal diameter) is $35 \mathrm{~cm}$ for class $\mathrm{A}$, and $25 \mathrm{~cm}$ for class $\mathrm{B}$. The nominal diameter has not been indicated for classes $C$ and $D$. The minimum length of the lower end without defects or with defects acceptable in classes $A$ and $B$ amounts to $4 \mathrm{~m}$. This value has not been limited for classes C and D. Class D is practically useless for industrial processing and is never ordered by sawmill in Poland. Most logs in the market fall in the $\mathrm{C}$ quality class and this is the class that is most frequently bought by lumber mills.

This study was aimed to determine whether the value of coefficient of determination between the width of annual growth rings and the bending strength, global MOE, and density of this kind of wood depends on the trunk part from which the log was taken and whether it depends on the quality of round logs from which timber samples were obtained. The presented results are part of a research project aimed at characterising Polishgrown pine timber in view of its use in construction, depending on the habitat and taking into account the entire process of timber production; which starts with the study of round logs. Similar projects have been studied in the past for different wood species in other European countries (Hanhijärvi et al. 2005; Hanhijärvi and Ranta-Maunus 2008; RantaMaunus et al. 2011). 


\section{EXPERIMENTAL}

\section{Materials}

The research materials consisted of pine timber from the Silesian Forestry Area in Poland. The sawn timber was made of raw material aged approximately 120 years, with $\log$ quality classes A, B, and C. The timber originated from logs of trees that grew in a fresh mixed forest under the Regional National Forest Directorate of Katowice (Olesno Forest District, Sternalice Forest Division, unit $14 \mathrm{~d}$, geographical coordinates: $\left.50^{\circ} 53 ' 55.1^{\prime \prime} \mathrm{N}, 18^{\circ} 25^{\prime} 26.1 " \mathrm{E}\right)$.

The basic parameters of the forest stand from which the wood for research was obtained are the following: dominant species alder, oak, pine; mean height $25 \mathrm{~m}$, mean diameter at breast height $32 \mathrm{~cm}$, site index II, technical quality 2, growing stock $224 \mathrm{~m}^{3} / \mathrm{ha}$, stocking 0.7 , share of pine $8 \%$.

The timber pieces used in the research were from three types of logs: butt, middle, and top. The timber was dried in industrial conditions in a chamber drier, down to the moisture content of $c a .12 \%$, and planed on four sides. The nominal dimensions of timber after drying and planing were: $40 \times 138 \times 3,500 \mathrm{~mm}^{3}$. The batch of timber under research included 210 pieces, 70 from each of the log type groups (butt, middle, and top). Taking into account the log quality classes, there were 17 pieces classified as $\mathrm{A}, 87$ pieces from quality class B, and 107 from class C, in accordance with PN-D-95017 (1992).

\section{Methods}

Measurement of annual growth rings width

The width of annual growth rings was measured in line with the Polish standard PN-D-94021 (2013). The samples used in the measurements had the dimensions of the entire cross-section of timber pieces $(40 \times 138 \mathrm{~mm})$ and were collected after the determination of bending strength, near the zone of failure. The measurement was taken along the line indicating the radial direction. The results were expressed as the average value of growth ring width, determined at a measurement section that was $75 \mathrm{~mm}$ long. The method consisted in counting the number of annual growth rings within the measurement section and calculating the average width of growth rings in that section. If the cross-section dimensions and growth ring layout made it impossible to establish a measurement section with the length of $75 \mathrm{~mm}$, then the measurements were conducted on a shorter section. If the sample contained pith, then the selected measurement section was at least $25 \mathrm{~mm}$ away from the pith.

\section{Global MOE and modulus of rupture (MOR) measurements in static bending}

The MOE and static bending strength also referred to as MOR in the edgewise position, were measured in accordance with the BS EN 408:2010 + A1 (2012) standard, using a 10 tonnes resistance machine TIRA Test 2300 (TIRA GmbH, Schalkau, Germany). The static diagram of the test is presented in Fig. 1. The tests were performed with control of movement. The speed of the crosshead was $3 \mathrm{~mm} / \mathrm{min}$. During the test, the authors registered the value of the load and the bend. Bending was determined with the help of additional equipment in the form of a movement sensor by Novotechnik, type TRS 75 (Southborough, MA, USA), with the precision of $0.01 \mathrm{~mm}$. Test results are shown in Table 1. 


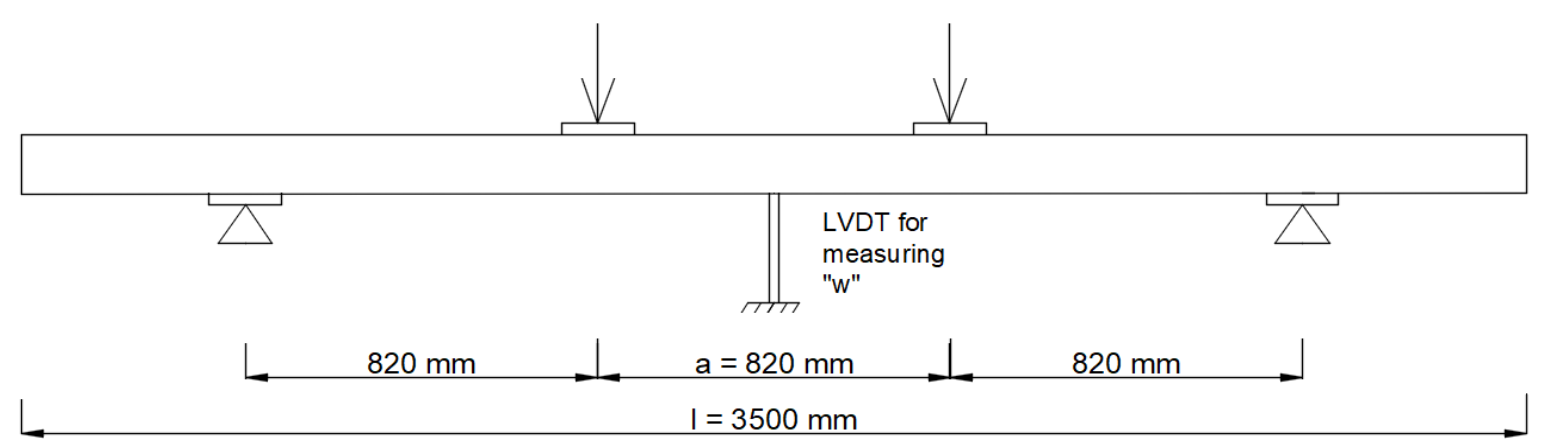

Fig. 1. Static diagram of destructive timber tests

Determination of timber density and water content

The water content of the timber batch was measured with the use of a HIT5 resistance wood moisture meter by TANEL Elektronika i Informatyka Spółka Jawna (Gliwice, Poland), with measurement precision of $0.1 \%$.

During the moisture measurements the species of wood under research and ambient temperature were taken into account. Timber density was determined with the stereometric method, in accordance with the BS EN 408:2010 + A1 (2012) standard. Test results are displayed in Table 1.

\section{Statistical analysis}

The statistical analysis of test results was performed in the Statistica v.13.3 software (StatSoft, Inc., Tulsa, OK, USA). The data were analysed and provided as the mean \pm standard deviation or the coefficient of variation. Additionally, the Student's T test was performed, with a confidence level of $95 \%$, to determine the significant differences between the mean values of the tested parameters in each analysed group. Moreover, a oneway analysis of variance (ANOVA) analysis was performed to determine whether the quality class of round logs and the trunk area from which the timber was acquired (butt, middle, or top) influenced its physico-chemical parameters (width of annual growth rings, density, MOE, and MOR).

One of the basic assumptions of this analysis was the normal distribution of the variable (physico-chemical parameter) under analysis. For all of the analysed cases, in each quality class (A, B, and C) and each area from which timber was obtained, the normal distribution of results was verified with the Kolmogorov-Smirnov test, with the minimum level of significance, $\mathrm{p}=0.05$.

The second basic assumption of the test was a homogeneous variance of the tested parameter, which was verified with the Levene's test. If the test confirmed the fulfillment of the zero hypothesis, the authors performed a post hoc test with the Turkey method. If the Levene's test revealed a lack of variance homogeneity for a given parameter, the authors used a corrective coefficient and an adequate method of post hoc test: the Duncan test. 


\section{RESULTS AND DISCUSSIONS}

The results of annual growth ring width measurements are presented in Table 1.

Table 1. Characteristics of Pine Timber Obtained from Logs of Each Class (A, $B$, and C) and Different Trunk Parts (Butt, Middle, and Top)

\begin{tabular}{|c|c|c|c|c|c|c|c|c|c|c|c|c|}
\hline & \multicolumn{3}{|c|}{$\begin{array}{c}\text { Width of Annual } \\
\text { Growth Rings (mm) }\end{array}$} & \multicolumn{3}{|c|}{ MOE (GPa) } & \multicolumn{3}{|c|}{ MOR (MPa) } & \multicolumn{3}{|c|}{ Density $\left(\mathrm{kg} / \mathrm{m}^{3}\right)$} \\
\hline $\begin{array}{c}\text { Log } \\
\text { Quality } \\
\text { Class }\end{array}$ & A & B & C & A & B & C & A & B & C & A & B & C \\
\hline Mean & 1.88 & 1.73 & 1.92 & 14.3 & 14.2 & 12.1 & 61 & 54 & 38 & 574 & 570 & 524 \\
\hline Min & 3.80 & 3.80 & 4.10 & 6.6 & 8.4 & 7.6 & 21 & 17 & 8 & 680 & 764 & 648 \\
\hline Max & 1.01 & 0.66 & 0.60 & 19.3 & 19.0 & 18.3 & 92 & 94 & 65 & 461 & 432 & 417 \\
\hline SD & 0.80 & 0.70 & 0.80 & 3.5 & 2.5 & 2.2 & 22 & 18 & 12 & 67 & 60 & 53 \\
\hline $\mathrm{N}$ & 17 & 86 & 107 & 17 & 86 & 107 & 17 & 86 & 107 & 17 & 86 & 107 \\
\hline $\begin{array}{l}\text { Log } \\
\text { Type }\end{array}$ & B & M & $\mathrm{T}$ & B & M & $\mathrm{T}$ & B & $\mathrm{M}$ & $\mathrm{T}$ & B & M & $\mathrm{T}$ \\
\hline Mean & 1.68 & 1.90 & 1.94 & 13.7 & 11.7 & 10.3 & 61 & 42 & 37 & 592 & 545 & 503 \\
\hline Min & 0.66 & 0.60 & 0.67 & 8.2 & 7.2 & 5.2 & 17 & 15 & 8 & 467 & 443 & 417 \\
\hline Max & 3.80 & 3.86 & 4.10 & 17.8 & 16.0 & 14.1 & 94 & 71 & 65 & 764 & 648 & 592 \\
\hline SD & 0.60 & 0.80 & 0.84 & 2.1 & 2.0 & 1.9 & 19 & 14 & 12 & 55 & 52 & 43 \\
\hline $\mathrm{N}$ & 70 & 70 & 70 & 70 & 70 & 70 & 70 & 70 & 70 & 70 & 70 & 70 \\
\hline
\end{tabular}

$\mathrm{B}$ - butt, $\mathrm{M}$ - middle, $\mathrm{T}$ - top

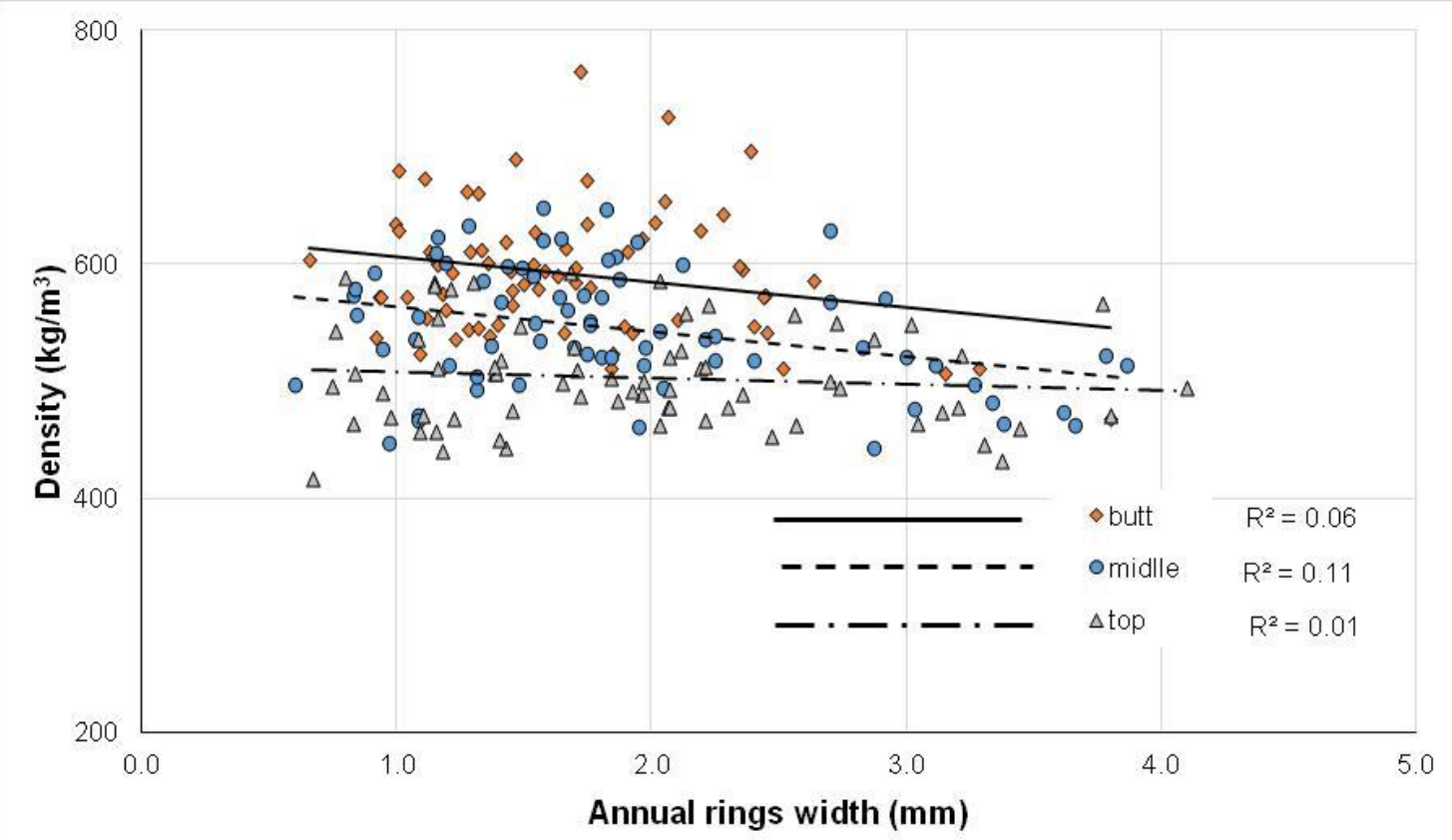

Fig. 2. Relation between the width of annual growth rings and wood density

The coefficient of determination between the width of annual growth rings and wood density (Fig. 2), determined on small samples for the entire batch of timber (210 pieces) amounted to 0.10 . This value was lower than the coefficient of determination between the width of annual growth rings and wood density determined during a previous 
study of 764 pieces of pine timber from different Polish forestry regions, which amounted to 0.20 (density of the whole board) and 0.24 (density of small sample) (Krzosek 2009). For Finnish pine timber, the coefficient of determination between the width of annual growth rings and timber density was up to 0.38 , and for Finnish spruce timber it was up to 0.35 (Hanhijärvi et al. 2005). The coefficient of determination between the width of annual growth rings and dry wood density measured for German coniferous timber amounted to 0.29 (Glos et al. 1999).

Taking into account the division of timber into butt, middle, and top logs, the highest value of coefficient of determination (0.11) was obtained for timber from middle logs. For butt logs, the coefficient of determination amounted to 0.06 . The lowest coefficient value (0.01) was observed for timber from top logs.

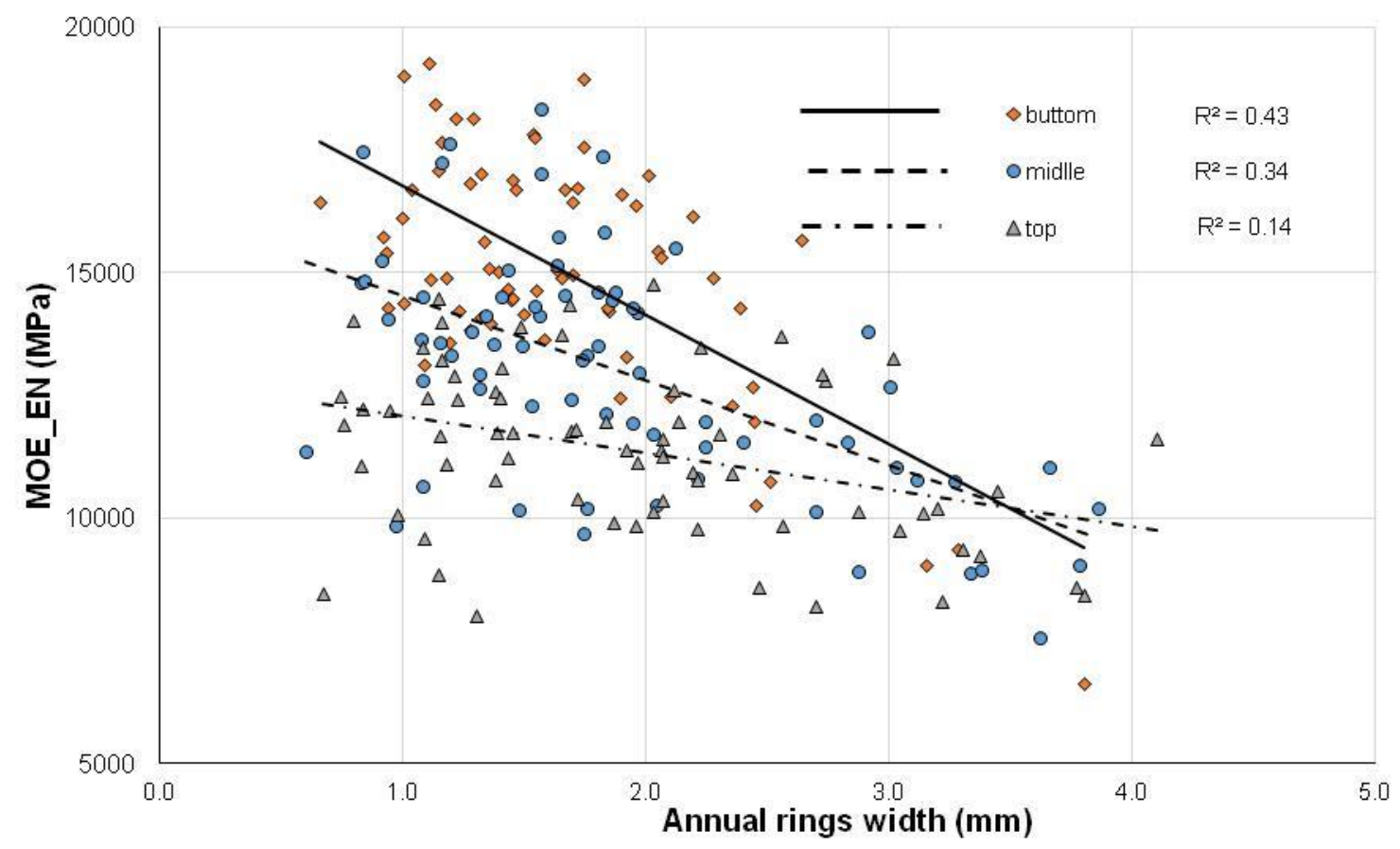

Fig. 3. Relation between the width of annual growth rings and the MOE

The coefficient of determination between the width of annual growth rings and the MOE during bending (Fig. 3), for the entire batch of timber (210 pieces) amounted to 0.17. This value was significantly lower than the coefficient of determination between the width of annual growth rings and the global MOE during bending determined in a previous study of 764 pieces of pine timber from various Polish forestry regions, which amounted to 0.29 (Krzosek 2009). For Finnish pine timber, the coefficient of determination between the width of annual growth rings and the global MOE amounted to 0.40, and for spruce timber, 0.53 (Hanhijärvi et al. 2005). Taking the division of timber into account to butt, middle, and top logs, the highest value of coefficient of determination (0.43) was obtained for timber from butt logs. For timber from middle logs, the coefficient of determination amounted to 0.34 . The lowest coefficient value $(0.14)$ was observed for timber from top logs. 


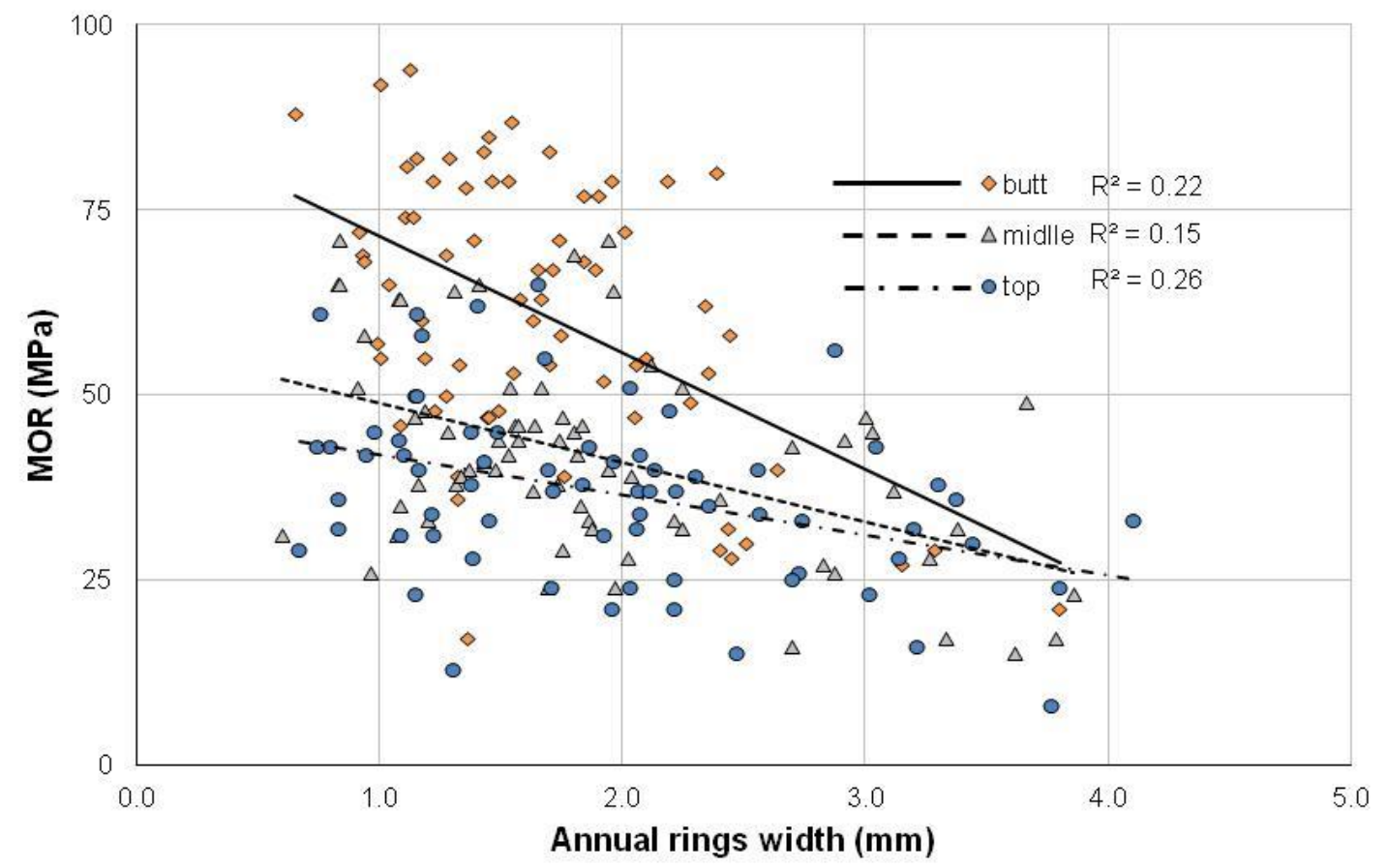

Fig. 4. Relation between the width of annual growth rings and static bending strength (MOR)

The coefficient of determination between the width of annual growth rings and the static bending strength (Fig. 4), for the entire batch of timber (210 pieces) amounted to 0.18 . This value was lower than the coefficient of determination between the width of annual growth rings and the static bending strength determined in a previous study of 764 pieces of pine timber from various Polish forestry regions, which amounted to 0.27 (Krzosek 2009). According to Bengtsson (2006), the coefficient of determination between the width of annual growth rings and the bending strength of European coniferous species falls between 0.20 and 0.44 . For Finnish pine timber, the coefficient of determination between the width of annual growth rings and the static bending strength amounted to 0.34, and for spruce timber to 0.38 (Hanhijärvi et al. 2005). In a German study of spruce timber (cross-section dimensions $40 \times 90 \mathrm{~mm}^{2}, 40 \times 180 \mathrm{~mm}^{2}, 60 \times 120 \mathrm{~mm}^{2}$, and $60 \times 180 \mathrm{~mm}^{2}$ ), the coefficient of determination between the width of annual growth rings and the bending strength amounted to 0.13 (Glos et al. 1988). In later studies of German spruce timber (Glos et al. 1999), the coefficient of determination between the width of annual growth rings and the bending strength amounted to 0.08. Taking into account the division of timber into butt, middle, and top logs in the cited studies, the highest value of coefficient of determination (0.26) was observed for timber from top logs. For timber from middle logs, the coefficient of determination was the lowest and amounted to 0.15 . For timber from butt logs, the coefficient of determination between the width of annual growth rings and the static bending strength amounted to 0.22 .

The next stage of the study was devoted to checking whether the quality class of the $\operatorname{logs}(\mathrm{A}, \mathrm{B}$, and $\mathrm{C})$ from which the pine timber was obtained had influence on the values of coefficient of determination between the width of annual growth rings and MOE, MOR, and timber density. 


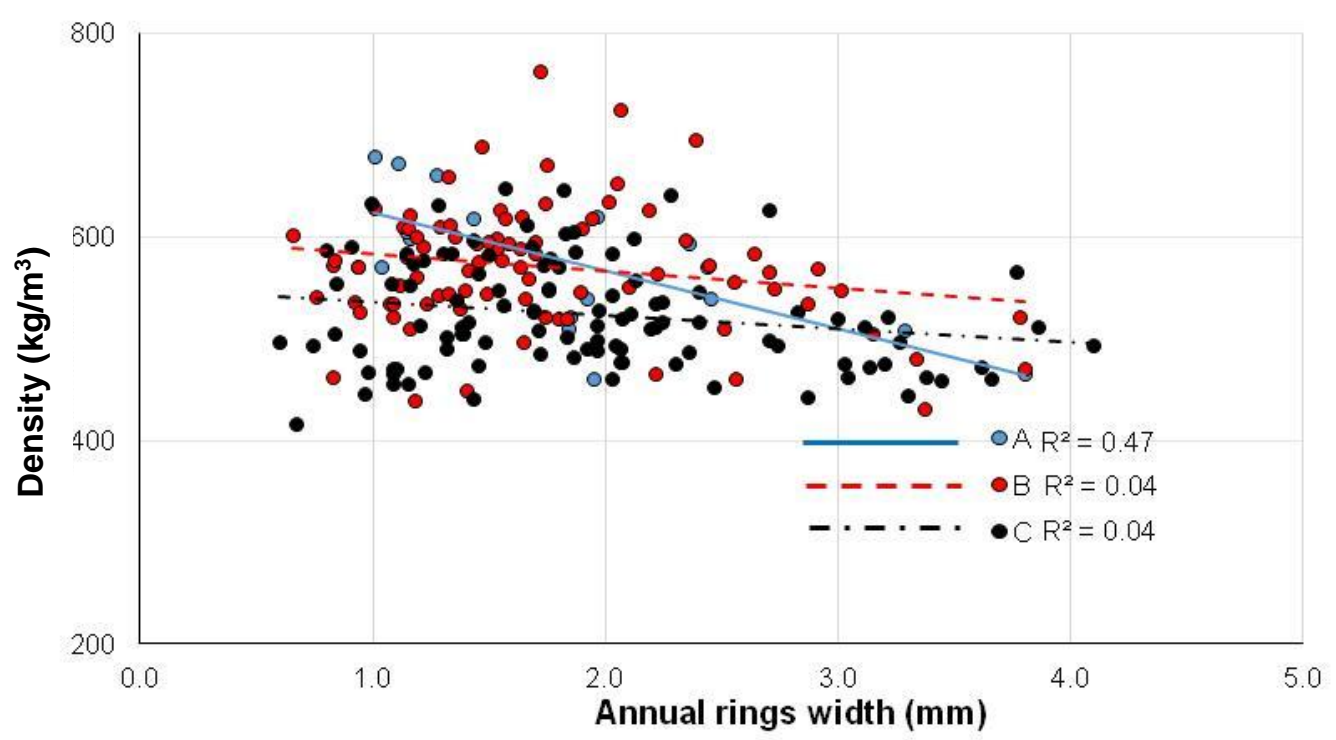

Fig. 5. Relation between the width of annual growth rings and the density of timber from the quality classes $\mathrm{A}, \mathrm{B}$, and $\mathrm{C}$

The coefficient of determination between the width of annual growth rings and wood density determined on small samples for the entire batch of timber (210 pieces) amounted to 0.10 . Taking into account the division of timber into different quality classes (A, B, and C), the highest value of coefficient of determination (0.47) was observed for timber from the A quality class. The coefficient values for classes $\mathrm{B}$ and $\mathrm{C}$ were similar: 0.04 for class B and 0.04 for class $\mathrm{C}$. These results demonstrated the fact that wood from the highest quality class (A) generally has the lowest amount of natural wood defects and is characterised by the highest correlation between the width of annual growth rings and wood density.

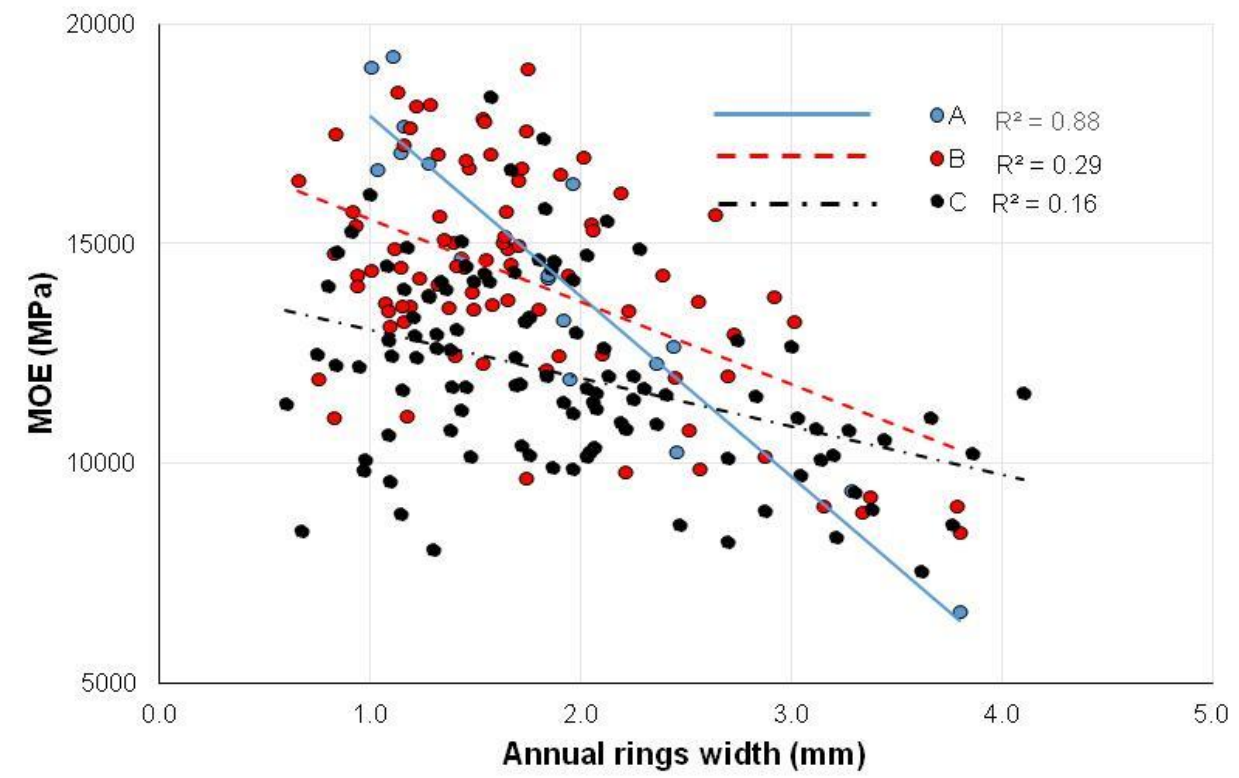

Fig. 6. Relation between the width of annual growth rings and the MOE of timber obtained from $\log$ quality classes $\mathrm{A}, \mathrm{B}$, and $\mathrm{C}$ 
The coefficient of determination between the width of annual growth rings and the global MOE (Fig. 6) during static bending MOE, for the entire batch of timber (210 pieces) amounted to 0.17 . For Finnish pine timber, the coefficient of determination between the width of annual growth rings and the global MOE amounted to 0.40, and for spruce timber, 0.53 (Hanhijärvi et al. 2005). Taking into account the division of timber into log quality classes (A, B, and C), the coefficient of determination between the width of annual growth rings and the global MOE at static bending achieved the highest value (0.88) for timber from the A quality class (the best class). For timber from the B quality class (the medium class) this coefficient amounted to 0.29 . For timber from the $\mathrm{C}$ quality class (the worst class) the tested coefficient amounted to 0.16 . The coefficient of determination for timber from the A quality class (the best one) was significantly higher than that of the entire timber batch and the timber from lower quality class. This can be explained by a small quantity of defects in the logs from the high quality class. Together with an increase in wood defects in the round logs (quality classes B and C), the coefficient of determination between the tested parameters (width of annual growth rings and MOE) is lower.

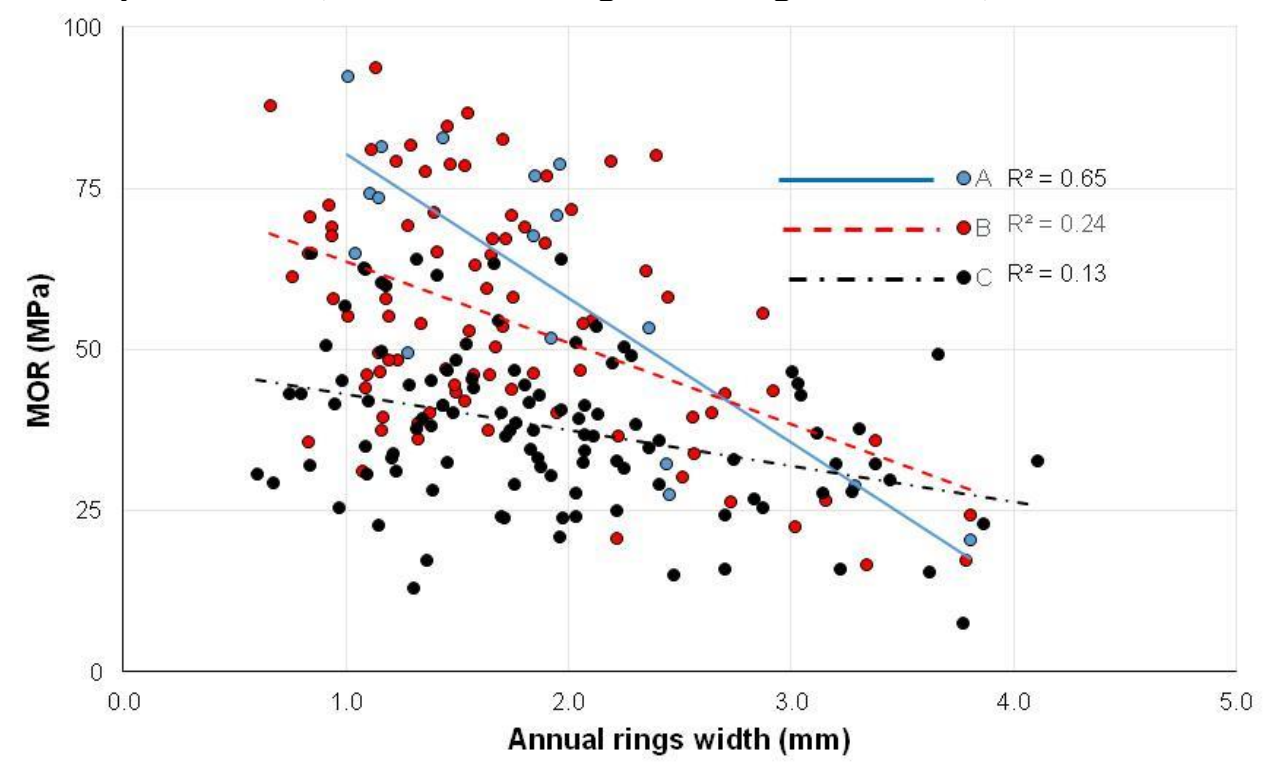

Fig. 7. Relation between the width of annual growth rings and the MOR of timber obtained from $\log$ quality classes $A, B$, and $C$

The coefficient of determination between the width of annual growth rings and the static bending strength (Fig. 7), for the entire batch of timber (210 pieces) amounted to 0.18 . Taking into account the division of timber into $\log$ quality classes $(\mathrm{A}, \mathrm{B}$, and $\mathrm{C})$, the coefficient of determination between the width of annual growth rings and MOR (static bending strength) for the tested pine timber was the highest in the logs from quality class $\mathrm{A}$, and amounted to 0.65 . For timber from the $\mathrm{B}$ quality class (the medium class) this coefficient amounted to 0.24 , and for class C, only 0.13. Additionally in this case, the coefficient of determination between the width of annual growth rings and static bending strength (MOR) for timber from the A quality class (the best one) was much higher than that of the entire timber batch and the timber from lower quality classes. This can be explained by a small quantity of defects in the logs from the high quality class. Together with an increase of wood defects in the round logs (quality classes B and C), the coefficient of determination between the tested parameters (width of annual growth rings and MOR) became lower. 
A comparison of the coefficients of determination between the tested parameters (Figs. 2 through 7) revealed that higher values were obtained for timber sorted according to the round $\log$ quality class $(\mathrm{A}, \mathrm{B}$, or $\mathrm{C}$ ) than according to the place of origin (butt, middle, or top logs). The situation was different for the relation between the width of annual growth rings and MOE, as well as the width of annual growth rings and MOR. Higher values of coefficient of determination between the width of annual growth rings and MOE, compared with the values of coefficient of determination between the width of annual growth rings and MOR, were observed only for timber from butt and middle logs and the logs from A and $\mathrm{B}$ classes. For timber from top logs and from class $\mathrm{C}$, the coefficients of determination between the width of annual growth rings and the MOE were lower than those between the width of annual growth rings and MOR. For top logs, the coefficient of determination: between width of annual growth rings and MOE amounted to 0.05; and between width of annual growth rings and MOR amounted to 0.15. Similarly, the coefficients of determination in $\operatorname{logs}$ from class $\mathrm{C}$, were 0.08 and 0.13 for width of annual growth rings and MOE and width of annual growth rings and MOR, respectively.

The ANOVA analysis revealed that the type of logs (butt, middle, or top) (Table 2) from the Silesian Forestry Area influenced the physical and mechanical parameters of pine timber made of those logs. The analysis revealed that there were significant differences in the values of wood density, MOE, and MOR in timber pieces obtained from different types of logs (butt, middle, and top). The value of the width of annual growth rings was not influenced, in any of the cases under analysis, by the quality variable (type of log and log quality class). Moreover, the analysis revealed that there were no significant differences in the values of timber density, MOE, and MOR for timber made of A and B quality logs. Only the lowest of the classes under analysis (C) showed statistically significant differences in the values of timber resistance parameters, both compared to timber made of A and B quality logs (Table 3 ). The plans to continue this research include additional analyses of wood from other Polish forestry regions, which will make it possible to verify the results obtained until now and to discover whether in other regions there are analogous correlations between the quality class of pine logs Pinus sylvestris L. and the mechanical properties of timber made of those logs.

Table 2. Probability of Post Hoc Tests for Log Types and Quality Classes as a Source of Variance in ANOVA Analysis

\begin{tabular}{|c|c|c|c|c|}
\hline \multirow{2}{*}{ Parameter } & \multirow{2}{*}{ Log Type } & \multicolumn{3}{|c|}{ Log Type } \\
\cline { 3 - 5 } & Butt & Butt & Middle & Top \\
\hline \multirow{3}{*}{ Rings Width } & Middle & 0.087337 & 0.087337 & 0.050420 \\
\cline { 2 - 5 } & Top & 0.050420 & - & 0.726066 \\
\cline { 2 - 5 } & Butt & - & 0.726066 & - \\
\hline \multirow{3}{*}{ Mensity } & Middle & $\mathbf{0 . 0 0 0 0 2 2}$ & $\mathbf{0 . 0 0 0 0 2 2}$ & $\mathbf{0 . 0 0 0 0 2 2}$ \\
\cline { 2 - 5 } & Top & $\mathbf{0 . 0 0 0 0 2 2}$ & - & $\mathbf{0 . 0 0 0 0 0 2 4}$ \\
\cline { 2 - 5 } & Butt & - & $\mathbf{0 . 0 0 0 0 2 2}$ & $\mathbf{0 . 0 0 0 0 2 2}$ \\
\hline & Middle & $\mathbf{0 . 0 0 0 0 2 2}$ & - & $\mathbf{0 . 0 0 0 0 6 0}$ \\
\cline { 2 - 5 } & Top & $\mathbf{0 . 0 0 0 0 2 2}$ & $\mathbf{0 . 0 0 0 0 6 0}$ & - \\
\cline { 2 - 5 } & Butt & - & $\mathbf{0 . 0 0 0 0 0 9}$ & $\mathbf{0 . 0 0 0 0 1 1}$ \\
\hline \multirow{3}{*}{ MOR } & Middle & $\mathbf{0 . 0 0 0 0 0 9}$ & - & $\mathbf{0 . 0 4 4 8 1 7}$ \\
\cline { 2 - 5 } & Top & $\mathbf{0 . 0 0 0 0 1 1}$ & $\mathbf{0 . 0 4 4 8 1 7}$ & - \\
\cline { 2 - 5 } & & & & \\
\hline
\end{tabular}


Table 3. Probability of Post Hoc Tests for Log Types and Quality Classes as a Source of Variance in ANOVA Analysis

\begin{tabular}{|c|c|c|c|c|}
\hline Parameter & Log Quality & \multicolumn{3}{|c|}{ Log Quality Class } \\
\cline { 2 - 5 } & Class & $\mathrm{A}$ & $\mathrm{B}$ & $\mathrm{C}$ \\
\hline \multirow{3}{*}{ Rings Width } & $\mathrm{A}$ & - & 0.372098 & 0.817089 \\
\cline { 2 - 5 } & $\mathrm{B}$ & 0.372098 & - & 0.292396 \\
\cline { 2 - 5 } & $\mathrm{C}$ & 0.817089 & 0.292396 & - \\
\hline \multirow{3}{*}{ Density } & $\mathrm{A}$ & - & 0.985408 & $\mathbf{0 . 0 2 9 2 3 3}$ \\
\cline { 2 - 5 } & $\mathrm{B}$ & 0.985408 & - & $\mathbf{0 . 0 0 0 0 2 2}$ \\
\cline { 2 - 5 } & $\mathrm{C}$ & $\mathbf{0 . 0 2 9 2 3 3}$ & $\mathbf{0 . 0 0 0 0 2 2}$ & - \\
\hline MOE & $\mathrm{A}$ & - & 0.894506 & $\mathbf{0 . 0 0 4 3 0 1}$ \\
\cline { 2 - 5 } & $\mathrm{B}$ & 0.894506 & - & $\mathbf{0 . 0 0 0 0 2 2}$ \\
\cline { 2 - 5 } & $\mathrm{C}$ & $\mathbf{0 . 0 0 4 3 0 1}$ & $\mathbf{0 . 0 0 0 0 2 2}$ & - \\
\hline \multirow{3}{*}{ MOR } & $\mathrm{A}$ & - & 0.097087 & $\mathbf{0 . 0 0 0 0 1 1}$ \\
\cline { 2 - 5 } & $\mathrm{B}$ & 0.097087 & - & $\mathbf{0 . 0 0 0 0 1 4}$ \\
\cline { 2 - 5 } & $\mathrm{C}$ & $\mathbf{0 . 0 0 0 0 1 1}$ & $\mathbf{0 . 0 0 0 0 1 4}$ & - \\
\hline
\end{tabular}

\section{CONCLUSIONS}

1. The correlations between the width of annual growth rings and modulus of rupture (MOR), modulus of elasticity (MOE), or wood density depended on the part from which the timber was obtained: the highest value was observed for butt logs and the lowest for top logs.

2. The correlation between growth ring width and MOE, MOR, or wood density depended also on the quality class of the logs that the timber was obtained from: it was the highest for timber from class $\mathrm{A}$, and the lowest for timber from class $\mathrm{C}$.

3. The type of Pinus sylvestris L. pine logs (butt, middle, or top) determined the values of physico-mechanical parameters of the timber made of them (density, MOE, and MOR). However, it did not influence the width of annual growth rings.

4. The quality class of Pinus sylvestris L. pine logs showed only a limited degree of influence on the physical and mechanical properties (density, MOE, and MOR) of timber produced from those logs. Timber made of high quality logs from classes A and B did not present statistically significant differences compared to the influence on the physical and mechanical parameters.

\section{ACKNOWLEDGMENTS}

The authors are grateful for the support of the National Centre for Research and Development, Poland, under "Environment, Agriculture, and Forestry" - BIOSTRATEG strategic R and D program, agreement No. BIOSTRATEG3/344303/14/NCBR/2018.

The authors would like to thank Martin Bacher (MiCROTEC GmbH·R\&D, Italy) for the consultations and valuable comments and Tomasz RÜDIGER (WTD Poznań, Poland) for the assistance in conducting research work. 


\section{REFERENCES CITED}

Bengtsson, C. (2006). "Grading structural timber," (http://www.coste53.net/downloads/Sopron/CostE53_Sopron-Bengtsson.pdf), COST, Accessed 27 Jan 2020.

Bouffier, L., Charlot, C., Raffin, A., Rozenberg, P., and Kremer, A. (2008). "Can wood density be efficiently selected at early stage in maritime pine (Pinus pinaster Ait.)?," Annals of Forest Science 65(1), Article Number 106. DOI: 10.1051/forest:2007078

Brüchert, F., Baumgartner, R., and Sauter, U. H. (2008). "Ring width detection for industrial purposes - Use of CT and discrete scanning technology on fresh roundwood," in: Proceedings of the End User's Needs for Wood Material and Products-COST E53 2008 Conference, Delft, Netherlands, pp. 157-163.

BS 4978:2007 + A1(2011). "Specification for visual strength grading of softwood," British Standards Institution, London, UK.

Council of the European Union (1988). "Council Directive 89/106/EEC of 21 December 1988 on the approximation of laws, regulations and administrative provisions of the Member States relating to construction products," Official Journal of the European Communities No L 40 (32), European Union, Brussels, Belgium.

Denzler, J. (2007). "Machine strength grading - An overview over existing machines," COST, (http://www.coste53.net/downloads/WG3/WG3-Hamburg/Lectures/COSTE53-WG3-Meeting-Hamburg-Denzler.pdf), Accessed 27 Jan 2020.

DIN 4074-1:2012. "Sortierung von Nadelholz nach der Tragfähigkeit [Strength grading of wood - Part 1: Coniferous sawn timber]," Nadelschnittholz. German Institute for Standardisation, Berlin, Germany.

EN 408:2010 + A1 (2012). "Timber structures. Structural timber and glued laminated timber. Determination of some physical and mechanical properties," European Committee for Standardization, Brussels, Belgium.

EN 1912 (2012). "Structural timber. Strength classes. Assignment of visual grades and species," European Committee for Standardization, Brussels, Belgium.

EN 15497 (2014). "Structural finger jointed solid timber. Performance requirements and minimum production requirements," European Committee for Standardization, Brussels, Belgium.

EN 338 (2016). "Structural timber. Strength classes," European Committee for Standardization, Brussels, Belgium.

EN 14081-1 (2015). "Timber structures. Strength graded structural timber with rectangular cross section- Part 1: General requirements," European Committee for Standardization, Brussels, Belgium.

EN 14080 (2013). "Timber structures. Glued laminated timber and solid timberRequirements," European Committee for Standardization, Brussels, Belgium.

EN 16351 (2015). "Timber structures- Cross laminated timber- Requirements," European Committee for Standardization, Brussels, Belgium.

European Commission (EC) Regulation 305/2011 (2011). "Regulation (EU) No 305/2011 of the European Parliament and of the Council of 9 March 2011 laying down harmonised conditions for the marketing of construction products and repealing Council Directive 89/106/EEC," European Union, Brussels, Belgium.

Gao, S., Wang, X., Wiemann, M., Brashaw, B., Ross, R., and Wang, L. (2017). “A critical analysis of methods for rapid and non-destructive determination of wood 
density in standing trees," Annals of Forest Science 74, Article number 27. DOI: 10.1007/s13595-017-0623-4

Gartner, B. L., North, E. M., Johnson, G. R., and Singleton, R. (2002). "Effects of live crown on vertical patterns of wood density and growth in Douglas-fir," Canadian Journal of Forest Research 32(3), 439-447. DOI: 10.1139/x01-218

Giagli, K., Timko, L., Gryc, V., and Vavrčík, H. (2019). "Is the quality of the non-native Douglas-fir wood produced in the Czech forests comparable to native softwoods?," BioResources 14(2), 2931-2945. DOI: 10.15376/biores.14.2.2931-2945

Glos, P. (1982). "Die maschinelle Sortierung von Schnittholz. Stand der technik Vergleich der Verfahren [Machine strength grading of timber. State of the art]," HolzZentrallblatt 108(13), 153-155.

Glos, P., Gamm, A., and Diebold, R. (1988). Ermittlung von Klassifizierungskriterien für Einheimischen Fichtenschnittholz mit Kleinen Querschnitten [Criteria for Grading of National Spruce Timber with Small Cross-sections] (Report No. 87503), Wood Research Munich, Munich, Germany.

Glos, P., Henrici, D., and Lederer, B. (1999). Verbesserung der Wettbewerbsfähigkeit der Sägeindustrie durch Erhöhung der Schnittholzqualität [Improvement of Competitiveness Sawmill Industry via Enhancement of Timber Quality] (Report No. 96507), Wood Research Munich, Munich, Germany.

Hanhijärvi, A., Ranta-Maunus, A., and Turk, G. (2005). Potential of Strength Grading of Timber with Combined Measurement Techniques (Report of the Combigrade Project phase 1), VTT Publications 568, Espoo, Finland.

Hanhijärvi, A., and Ranta-Maunus, A. (2008). Development of Strength Grading of Timber Using Combined Measurement Techniques (Report of the Combigradeproject phase 2), VTT Publications 686, Espoo, Finland.

Hoffmeyer, P. (1990). Failure of Wood as Influenced by Moisture and Duration of Load, Doctoral Thesis, State University of New York College of Environmental Science and Forestry, Syracuse, NY, USA.

Krzosek, S. (2009). Wytrzymałościowe Sortowanie Polskiej Sosnowej Tarcicy Konstrukcyjnej Rożnymi Metodami [Strength Grading of Polish Pine Structural Sawn Timber], Wydawnictwo SGGW, Warsaw, Poland.

Lackner, R., and Foslie, M. (1988). Gran af Vestlandet-Styrke og Sortering [Spruce from Western Norway. Strength and Sorting], Medd.74. Norsk Treteknisk Institutt, Oslo, Norway.

NF B 52-001-1:2011. "Règles d'utilisation du bois dans la construction. Classement Visual pour l'emploi en structures des bois sciès Francis rèsineux et feuillus. Partie 1: Bois Massie [Regulations governing the use of timber in structure - Visual classification for the use of French softwood and hardwood species in structures Part 1 : massive wood]," French Association for Standardisation, La Plaine Saint Denis Cedex, France.

Niklas, K. J. (1997). "Mechanical properties of black locust (Robinia pseudoacacia L.) wood size- and age-dependent variations in sap- and heartwood," Annals of Botany 79(5), 265-272. DOI: 10.1006/anbo.1996.0372

ÖNORM-DIN 4074-1:2012. "Sortierung von Nadelholz nach der Tragfähigkeit [Strength grading of wood - Part 1: Coniferous sawn timber]," Nadelschnittholz. Austrian Standards Institute, Vienna, Austria. 
PN-D-94021 (2013). "Tarcica konstrukcyjna iglasta sortowana metodami wytrzymałościowymi [Coniferous structural timber sorted by strength methods]," Polish Committee for Standardization, Warsaw, Poland.

PN-D-95017 (1992). "Surowiec drzewny. Drewno wielkowymiarowe iglaste [Wooden raw materials. Large dimension coniferous wood]," Polish Committee for Standardization, Warsaw, Poland.

Ranta-Maunus, A., Denzler, J., and Stapel, P. (2011). Strength of European Timber. Properties of Spruce and Pine Tested in Gradewood Project (Report of the Combigrade - project phase 2), VTT Publications 179, Espoo, Finland.

Steffenrem, A., Kvaalen, H., Dalen, K. S., and Høibø, O. A. (2014). “A high-throughput X-ray-based method for measurements of relative wood density from unprepared increment cores from Picea abies," Scandinavian Journal of Forest Research 29(5), 506-514. DOI: 10.1080/02827581.2014.919350

STN 49 1531:2001+Z1:2006. "Drevo na stavebné konštrukcie. Čast 1: Vizuálne tredienie podl'a pevnosti [Timber for engineering structures]," Slovak Office of Standards, Metrology and Testing, Bratislava, Slovakia.

Tomczak, A., Pazdrowski, W., and Jelonek, T. (2007). "Distribution of intermediate and mature wood on the longitudinal cross section of the tree trunk and selected biometric traits of the Scots pine (Pinus sylvestris L.)," Baltic Forestry 13(1), 116-125.

UNI 11035-2:2010. "Legno strutturale classificazione a vista dei legnami secondo la resistenza meccanica. Parte 2: Regole per la classificazione a vista secondo la resistenza meccanica e valori caratteristici per tipi di legname struttura [Structural timber - Visual strength grading for structural timbers - Part 2: Visual strength grading rules and characteristics values for structural timber population]," Italian National Unification, Milan, Italy.

Article submitted: January 28, 2020; Peer review completed: April 3, 2020; Revised version received and accepted: May 11, 2020; Published: May 22, 2020.

DOI: $10.15376 /$ biores. 15.3.5402-5416 